\title{
Orbital Sarcoma pT2 TNM Finding v8
}

National Cancer Institute

\section{Source}

National Cancer Institute. Orbital Sarcoma pT2 TNM Finding v8. NCI Thesaurus. Code C140844.

Orbital sarcoma with tumor measuring more than $2 \mathrm{~cm}$ in greatest diameter without invasion of bony walls or globe. (from AJCC 8th Ed.) 